\title{
Microcephaly epidemic related to the Zika virus and living conditions in Recife, Northeast Brazil
}

\author{
Wayner Vieira de Souza ${ }^{1 *}$, Maria de Fátima Pessoa Militão de Albuquerque ${ }^{1}$, Enrique Vazquez², \\ Luciana Caroline Albuquerque Bezerra ${ }^{3}$, Antonio da Cruz Gouveia Mendes ${ }^{1}$, Tereza Maciel Lyra ${ }^{1}$, \\ Thalia Velho Barreto de Araujo ${ }^{4}$, André Luiz Sá de Oliveira', Maria Cynthia Braga', \\ Ricardo Arraes de Alencar Ximenes ${ }^{4,5}$, Demócrito de Barros Miranda-Filho ${ }^{5}$, \\ Amanda Priscila de Santana Cabral Silva ${ }^{1}$, Laura Rodrigues ${ }^{6}$ and Celina Maria Turchi Martelli ${ }^{1,7}$
}

\begin{abstract}
Background: Starting in August 2015, there was an increase in the number of cases of neonatal microcephaly in Northeast Brazil. These findings were identified as being an epidemic of microcephaly related to Zika virus (ZIKV) infection. The present study aims to analyse the spatial distribution of microcephaly cases in Recife (2015-2016), which is in Northeast Brazil, and its association with the living conditions in this city.
\end{abstract}

Methods: This was an ecological study that used data from reported cases of microcephaly from the State Health Department of Pernambuco (August 2015 to July 2016). The basic spatial unit of analysis was the 94 districts of Recife. The case definition of microcephaly was: neonates with a head circumference of less than the cut-off point of -2 standard deviations below the mean value from the established Fenton growth curve. As an indicator of the living conditions of the 94 districts, the percentage of heads of households with an income of less than twice the minimum wage was calculated. The districts were classified into four homogeneous strata using the K-means clustering algorithm. We plotted the locations of each microcephaly case over a layer of living conditions.

Results: During the study period, 347 microcephaly cases were reported, of which 142 (40.9\%) fulfilled the definition of a microcephaly case. Stratification of the 94 districts resulted in the identification of four strata. The highest stratum in relation to the living conditions presented the lowest prevalence rate of microcephaly, and the overall difference between this rate and the rates of the other strata was statistically significant. The results of the Kruskal-Wallis test demonstrated that there was a strong association between a higher prevalence of microcephaly and poor living conditions. After the first 6 months of the study period, there were no microcephaly cases recorded within the population living in the richest socio-economic strata.

Conclusion: This study showed that those residing in areas with precarious living conditions had a higher prevalence of microcephaly compared with populations with better living conditions.

Keywords: Zika, Ecological study, Socio-economic, Brazil

\footnotetext{
* Correspondence: wayner@cpqam.fiocruz.br

${ }^{1}$ The Aggeu Magalhães Research Center -FIOCRUZ/PE, Av. Professor Moraes

Rego, s/n Cidade Universitária, Recife, Pernambuco CEP 50.740-465, Brazil

Full list of author information is available at the end of the article
}

(c) The Author(s). 2018 Open Access This article is distributed under the terms of the Creative Commons Attribution 4.0 International License (http://creativecommons.org/licenses/by/4.0/, which permits unrestricted use, distribution, and reproduction in any medium, provided you give appropriate credit to the original author(s) and the source, provide a link to the Creative Commons license, and indicate if changes were made. The Creative Commons Public Domain Dedication waiver (http://creativecommons.org/publicdomain/zero/1.0/) applies to the data made available in this article, unless otherwise stated. 


\section{Background}

Zika virus (ZIKV) is a Flaviviridae that can currently be characterized as one of the most significant emerging arboviruses in the Americas considering how widespread its infection has become. The first reports of the circulation of this virus go back to 1947 in Uganda among non-human primates. The first reported human case dates back to 1954 in Nigeria $[1,2]$.

The first recorded outbreak of the virus outside of the continent of Africa occurred on the Yap Islands in Micronesia in 2007, which was followed by outbreaks in French Polynesia in 2013 and 2014 [3, 4]. During these outbreaks, the disease was identified as being characterized mainly by a rash and arthralgia. The Zika infection was associated with Guillain-Barré syndrome in the adult population of French Polynesia [5].

The circulation of ZIKV was first reported in South America in 2014 [6]. Towards the end of 2014 and beginning of 2015, several cities in Northeast Brazil reported an outbreak of an exanthaematous disease that was clinically different from dengue. The first confirmed case of ZIKV infection in the country occurred in March 2015 [7].

Starting in August 2015, there was an increase in the number of cases of neonatal microcephaly in Pernambuco and throughout other states in Northeast Brazil compared to previous patterns [8]. This region aggregated approximately $90 \%$ of the 1501 livebirths that were registered as having microcephaly, which was investigated from November 2015 to February 2016 [9]. This epidemic of microcephaly of an unknown aetiology was promptly declared as being a national public health emergency by the Brazilian Ministry of Health in November 2015 [10]. These space and time clusters of microcephaly were described in series of cases studies reporting on neonates with a foetal brain disruptive sequence, a previously rare phenotype involving microcephaly and cerebral abnormalities, who also had presumptive or confirmed in utero ZIKV infection $[11,12]$. Subsequently, a causal relationship was established between ZIKV infection and congenital ZIKA syndrome, which includes microcephaly and other abnormalities [13-15].

The transmission of vector-borne diseases is currently a public health challenge in urban areas [16]. Previous studies on dengue conducted in the city of Recife in Northeast Brazil reported a variable disease prevalence that was based on the place of residence. This is a reflection of the poor living conditions: overcrowding, high mobility and high exposure to the infected vectors [17]. This same socioeconomic pattern has been seen in Bancroftian filariasis, which was a major endemic public health problem for several decades [18-20]. There are important social inequalities that exist in the inner city, but universal access to healthcare is warranted by a public health system $[21,22]$.
Within the context of the Zika epidemic, there is a lack of information regarding the relationship between the occurrence of microcephaly and the socio-economic conditions in the urban environment. The present study analyses the spatial distribution of the microcephaly cases in the epidemic in Recife (2015-2016) and its association with living conditions.

\section{Methods}

This study was conducted in the city of Recife in Northeast Brazil. The city is located on the Atlantic coastal plain ( $\left.8^{\circ} 03^{\prime} \mathrm{S} 34^{\circ} 52^{\prime} \mathrm{W}\right)$, has an area of $218 \mathrm{~km}^{2}$ and is divided into 94 districts. It has a population of 1.5 million (Fig. 1). This implies that it has a population density of approximately 7000 inhabitants per square kilometre, which is one of the highest in Brazil. The human development index for the city was 0.772 , and only $69 \%$ percent of the population was connected to the sewage system in 2010 [21].

This is an ecological study that uses data from reported cases of microcephaly during a one-year period from 02/ $08 / 2015$ to $31 / 07 / 2016$. These data were provided by an electronic surveillance system that was setup by the Ministry of Health and the State Health Department of Pernambuco. The cases are reported by the health services professionals in this real time system, generating a database managed by this State Department. The district was the basic spatial unit of analysis in this study.

For the present study, a case definition of microcephaly refers to those neonates with a head circumference of less than the cut-off point of -2 standard deviations (SDs) below the mean value from the established Fenton growth curves according to sex and gestational age. The choice of the -2 SD cut-off was due to its higher sensitivity for screening suspected microcephaly cases compared with the -3 SD cut-off, which is a more specific choice.

The Brazilian minimum wage in December 2016 was $880.00 \mathrm{BRL}$, which is equivalent to approximately 260.00 USD [23]. As an indicator for the living conditions, the percentage of heads of households with an income of less than twice the minimum wage (1760 BRL/month), including head of households with no income, was calculated for each district using data from the 2010 census. The city of Recife has a diverse ethnic population mainly composed by European, Black Africans and Indigenous descendents. The majority of the residents are non-white/black that has lower income compared to the white population, according to demographic census [24]. Subsequently, the 94 districts of the city of Recife were classified into four homogeneous strata in terms of living conditions using the K-means clustering algorithm [25]. This technique allows for the identification of homogeneous groups of districts according to the 


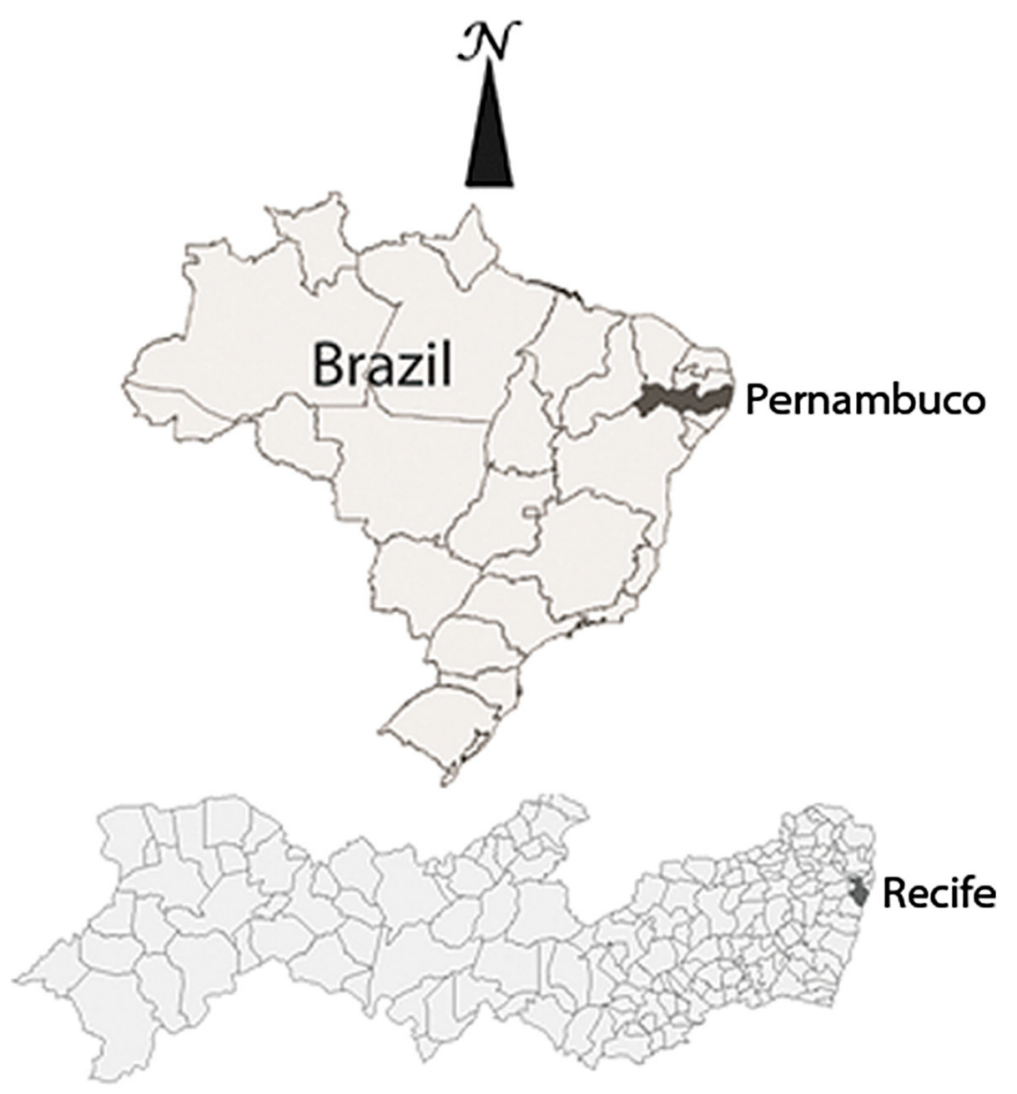

Fig. 1 Location of the capital city of Recife, Pernambuco State, Brazil

indicator used. It establishes intra-strata homogeneity and between-strata heterogeneity. Statistically, this aims to maximize the variance between the groups and minimize the variance within each group.

The microcephaly cases were georeferenced with QGIS software (QGIS Development Team, 2015. QGIS Geographic Information System. Open Source Geospatial Foundation.

https://qgis.org/en/site/) through the geocoding tool that transforms registered addresses into a tabular database for the database of sites stored in QGIS and returns the result in the form of geographical coordinates (latitude and longitude) for all of the addresses. The cartographic basis for the city of Recife was provided by the Brazilian Institute of Geography and Statistics (IBGE) website in the shapefile format in the "geographic" projection system (latitude and longitude) and SIRGAS 2000 [26], which was updated in 2010.

First, we produced a thematic map of the living conditions. Second, we plotted the residential location of each of the microcephaly cases over a layer of living conditions.

It should be noted that this map was made at a scale of 1: 100,000, which produces an error of approximately $20 \mathrm{~m}$ on the real scale $(0.2 \mathrm{~mm}$ on the map). Therefore, the residence of each case was located in a broad circle of approximately $1250 \mathrm{~m}^{2}$ in a highly urbanized city. Consequently, the precise location of each residence was not possible in this mapping procedure and ethical concerns are not applicable.

To analyse the prevalence of microcephaly among the districts according to the different strata of living conditions, we used the non-parametric Kruskal-Wallis test for independent samples.

\section{Results}

The stratification of the 94 districts according to the percentage of heads of households with a monthly income of less than twice the minimum wage, from which four strata were identified (Table 1).

We performed the K-means procedure with the ANOVA test, and the $\mathrm{F}$ value was higher for 4 strata $(F=570.6 ; \mathrm{df}=89)$ compared to 3 strata $(F=523.4 ; \mathrm{df}$ $=90)$ and 5 strata $(F=527.3 ; \mathrm{df}=88)$.

The mean per capita monthly incomes of the populations observed for the strata were 2868.88 BRL (1), 1616.73 BRL (2), 674.76 BRL (3) and 340.70 BRL (4).

Figure 2 presents the Recife neighbourhoods aggregated according to the strata of living conditions. 
Table 1 Districts and populations of Recife, Brazil in 2010 stratified according to the living conditions

\begin{tabular}{lllll}
\hline Strata & Districts $(\mathrm{n})$ & Population & $\%$ & Strata Centre $^{\mathrm{a}}$ \\
\hline 1 & 14 & 205,926 & 13.5 & 22.2 \\
2 & 10 & 100,351 & 6.6 & 40.0 \\
3 & 30 & 533,540 & 35.1 & 68.1 \\
4 & 40 & 680,762 & 44.8 & 88.0 \\
Total & 94 & $1,520,579$ & 100 & - \\
\hline
\end{tabular}

${ }^{\mathrm{a}}$ Final strata Centres (\% of heads of households with an income below twice the minimum wage) in the K-means analysis; $\mathrm{df}=3 ; F=570.6 ; P<0.0001$
During the study period, 347 suspected cases of microcephaly were reported, of which 142 (40.9\%) fulfilled the study definition of a microcephaly case.

Table 2 presents the number of microcephaly cases, the prevalence rates calculated for each stratum of living conditions and the results for the Kruskal-Wallis test for association.

The highest socio-economic stratum presented the lowest microcephaly prevalence rate, and the overall difference between this rate and the rates of the other strata was statistically significant. The stratum of the higher

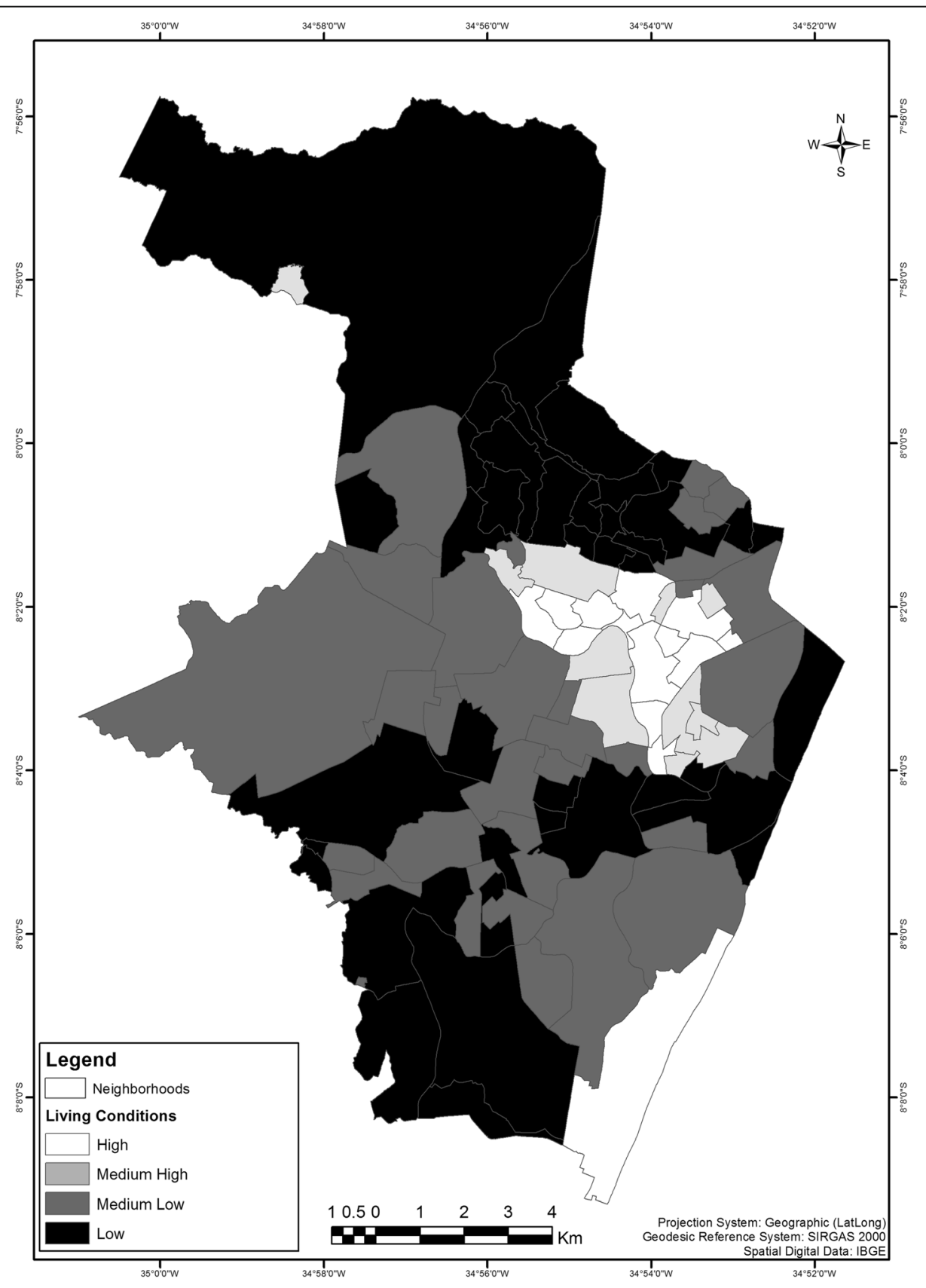

Fig. 2 Neighbourhoods and living conditions of Recife, Northeast Brazil, according to the 2010 census data 
Table 2 Prevalence rates of microcephaly stratified by the living conditions in Recife, Brazil

\begin{tabular}{llllll}
\hline Strata & $\begin{array}{l}\text { Microcephaly } \\
\text { Notified }\end{array}$ & $\begin{array}{l}\text { Microcephaly } \\
\text { Cases }\end{array}$ & Newborns & $\begin{array}{l}\text { Prevalence } \\
\text { per } 10,000 \\
\text { newborns }\end{array}$ \\
\hline 1 & 10 & 3 & 2487 & 12.1 & $2.5-35.2$ \\
2 & 21 & 8 & 1290 & 62.0 & $26.8-121.8$ \\
3 & 116 & 55 & 7984 & 68.9 & $51.9-89.6$ \\
4 & 200 & 76 & 11,417 & 66.6 & $52.5-83.3$ \\
TOTAL & 347 & 142 & 23,178 & 61.3 & $51.6-72.2$ \\
\hline
\end{tabular}

Kruskal-Wallis test: $\mathrm{X}^{2}=10.94 ; p=0.012$

living conditions had 3 microcephaly cases in 2487 live births, which is compared to 139 cases in 20,691 live births for the other strata. This implies that there was a prevalence ratio (PR) of 5.6 (95\% CI: 1.8 to 17.5 ).

Figure 3 illustrates the results above, presenting the low occurrence of microcephaly cases in the moreprivileged districts of the city.

These results indicate that there is a strong association between a higher prevalence of microcephaly and poor living conditions.

Moreover, it was observed that microcephaly cases occurred in only 2 of the 14 districts of stratum 1 and in 4 of the 10 districts of stratum 2 . In addition, all of the cases that occurred in strata 1 and 2 did so during the first 6 months of the epidemic (August 2015 to January 2016), while in strata 3 and 4,27\% of the cases (35 out of 131) occurred between February 2016 and July 2016.

\section{Discussion}

In the present study, we showed that residing in areas with precarious living conditions was associated with a higher prevalence of microcephaly compared to residing in areas with better living conditions.

The causal relationship between congenital ZIKV infection and microcephaly has become evident [13-15], but the association between microcephaly and living conditions has not yet been explored. We used a framework of socio-economic conditions to depict the distribution of microcephaly cases in the city of Recife. The strata of socio-economic conditions showed that approximately $40 \%$ of the urban population of the city of Recife lives in districts where the heads of households earn a low monthly income. The evaluation of strata by living conditions revealed small wealthy inner-city areas surrounded by large, populated deprived areas, except for the more recently urbanized southern area located along the coastline. The city of Recife has a high population density and is crossed by two rivers. The yearround temperature and humidity levels combined with clusters of inadequate houses built in overcrowded areas without basic sanitation provide an ideal environment for the transmission of vector-borne diseases such as filariasis and dengue and now Zika and Chikungunya $[18,20,27]$. Within the global scenario, increased amounts of unplanned urbanization has transformed the urban areas of poor and middle-income countries into breeding grounds for vector-borne diseases [16]. The discussion of social and living condition inequalities and the consequent social determinants of health highlights important issues related to infectious and non-infectious diseases [22, 28].

It should be mentioned that the analysis of the spatial distribution of microcephaly cases was performed shortly after the first wave of the ZIKV infection in Recife, a densely populated city in Northeast Brazil. The point pattern map of microcephaly cases shows that the bulk of microcephaly cases related to the epidemic were in deprived areas. Only three out of the 142 cases were located in the stratum of the wealthiest district and were identified in the first months of the epidemic. The interpretation of this finding is complex. In Brazil, abortion is legal only in cases for which there is risk to the mother's life and in cases of rape. Our study does not allow for the evaluation of whether women with better socio-economic conditions have easier access to abortion and other ways for preventing Zika virus exposures.

In the study area, after almost 30 years of dengue virus circulation, there is still a significant association between dengue seroprevalence and the living conditions in the city of Recife [17]. The population living in low-income areas was more prone to previous dengue infection (91.1\%) than that in areas with better living conditions (74.3\%) according to a large survey conducted in 2010 [17]. Nevertheless, according some authors [29], dengue transmitted by Aedes aegypti is not strictly considered a disease of poverty, which is based on outbreaks in cities that could be described as wealthy.

One limitation of our study is that the case definition of microcephaly refers only to the head circumference measurement of neonates and does not take into account other clinical and/or laboratory assessments. However, this was the notification criteria used during the study period. Furthermore, it should be noted that the adopted criterion (2 SDs) differs slightly from that previously used (below the third percentile of the Fenton Curve). Thus, it approaches the conditions established by the Intergrowth method, which is currently recommended. Our findings are also prone to the limitation that is inherit in ecological studies, and the spatial unit of analysis used may not be homogenous in terms of the socio-economic conditions. In addition, the number of cases was insufficient for more stratified analyses.

Our findings raise an interesting hypothesis about the spatial heterogeneity of microcephaly occurrence related 


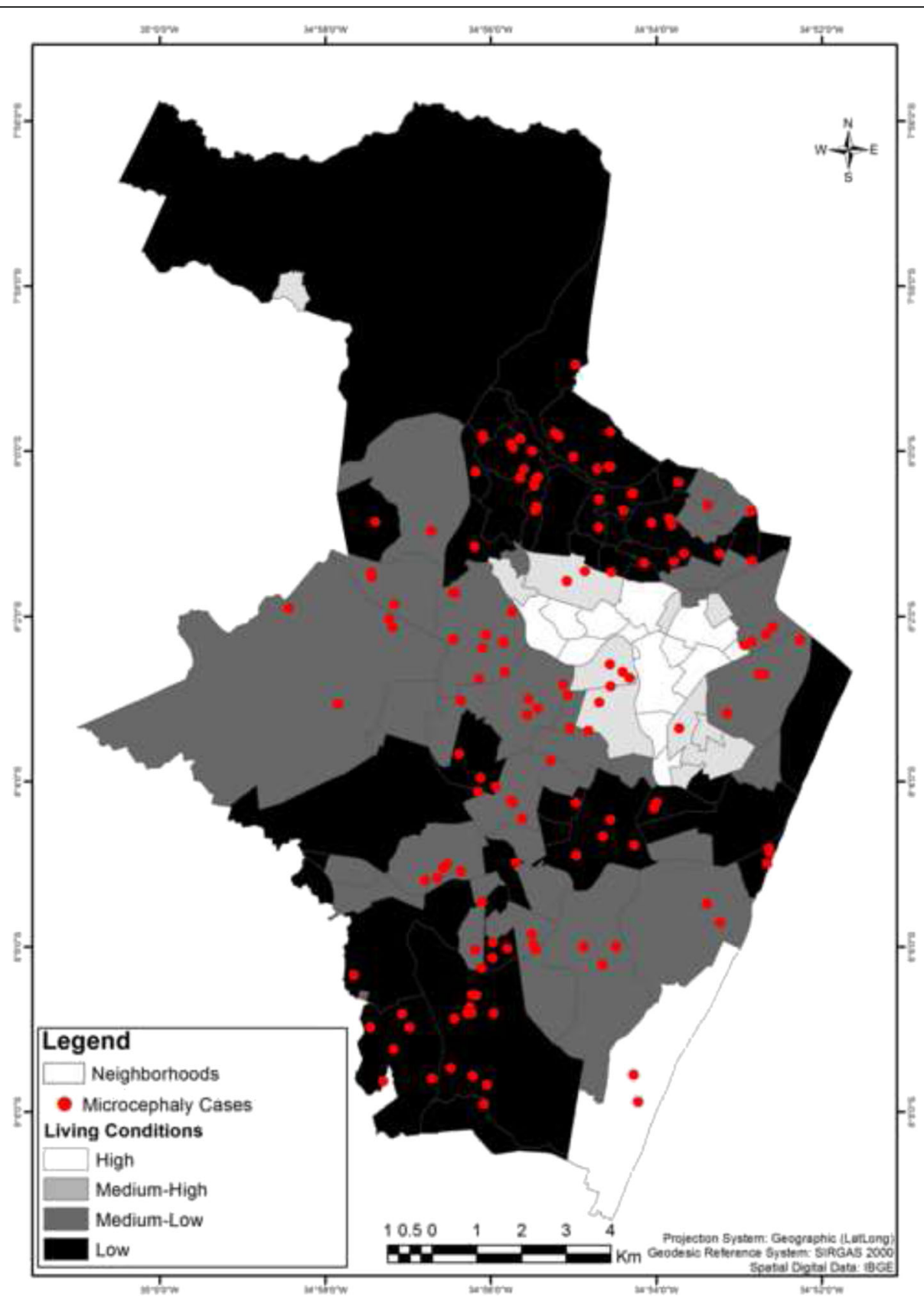

Fig. 3 Microcephaly cases and living conditions of the residents of Recife, Brazil

to living conditions. We are aware that our findings are the first that resulted from using an approach with an ecological design. Exploring the impact of living conditions and other factors should be taken into account to explain the risk differences of microcephaly events at the individual level in epidemic and post-epidemic contexts.

\section{Conclusion}

Our research highlights that residing in urban areas with precarious living conditions is associated with a higher prevalence of microcephaly compared with residing in areas with better living conditions.

Monitoring the spatial distribution of microcephaly cases and its correlation with living conditions, in addition to seroprevalence surveys for circulating arbovirus, could be a valuable tool for the assessment of the dynamics of intra-urban disease transmission. The overlap of the layers of disease occurrence and deprived areas is useful for public health interventions such as vector control. 


\section{Acknowledgements}

The investigators received partial support from the National Advisory Board of Scientific and Technological Development (Conselho Nacional de Desenvolvimento Cientifico e Tecnologico [CNPq]; scholarship 306708/2014-0 to CMTM, scholarship 308818/2013-0 to RAAX, scholarship 308590/2013-9 to DBM-F, scholarship 308491/ 2013-0 to MFPMA, scholarship 304174/2014-9 to MCB, and scholarship 306222/ 2013-2 to WWS). LR is partly funded by the European Union's Horizon 2020 research and innovation program under Zika-PLAN (grant agreement no. 734584).

\section{Funding}

The Brazilian Ministry of Health and Pan American Health Organization funded this study.

\section{Availability of data and materials}

Not applicable.

\section{Authors' contributions}

WWS, MFPMA, CMTM and LR designed the study, analyzed the data and written the manuscript. ACGM, TML, TVBA, MCB, RAAX and DBM-F participated in the interpretation of the results, the construction of the Discussion and the critical review of the manuscript. ALSO and APSCS participated in geoprocessing of data, interpretation of results and critical review of the manuscript. EV and LCAB and participated in the interpretation of the results and critical review of the manuscript. All authors read and approved the final manuscript.

\section{Author information}

The investigators are from the Microcephaly Epidemic Research Group, Brazilian Ministry of Health, Pan American Health Organization and State Health Department of Pernambuco.

\section{Ethics approval and consent to participate}

We received permission of Pernambuco Health State Department to use the anonymous data for research purpose.

\section{Consent for publication}

Not applicable.

\section{Competing interests}

We declare that there are no competing interests to disclose.

\section{Publisher's Note}

Springer Nature remains neutral with regard to jurisdictional claims in published maps and institutional affiliations.

\section{Author details}

'The Aggeu Magalhães Research Center -FIOCRUZ/PE, Av. Professor Moraes Rego, s/n Cidade Universitária, Recife, Pernambuco CEP 50.740-465, Brazil. ${ }^{2}$ Pan American Health Organization, Setor de Embaixadas Norte, Lote 19, Brasília CEP 70800-400, Brazil. ${ }^{3}$ Pernambuco State Health Department, Rua Dona Maria Augusta Nogueira, 519, Bongi, Recife, Pernambuco CEP 50751-530, Brazil. ${ }^{4}$ Universidade Federal de Pernambuco, Av. Prof. Moares Rego, 1235, Cidade Universitáia, Recife, Pernambuco CEP 50670-901, Brazil. ${ }^{5}$ Universidade de Pernambuco, Avenida Agamenon Magalhães, S/N, Santo Amaro, Recife, Pernambuco CEP 501100-010, Brazil. 'London School of Hygiene \& Tropical Medicine, Keppel Street, London, UK. ${ }^{7}$ Universidade Federal de Goiás, Avenida Esperança, S/N, Campus Samambaia, Goiânia, Goiás CEP 74690-900, Brazil.

Received: 7 February 2017 Accepted: 5 January 2018 Published online: 12 January 2018

\section{References}

1. Wikan N, Smith DR. Zika virus: history of a newly emerging arbovirus. Lancet Infect Dis. 2016;16:e119-26. https://doi.org/10.1016/S1473-3099(16)30010-X.

2. Plourde AR, Bloch EM. A Literature Review of Zika Virus. Emerging Infectious Diseases. 2016;22:1185-92. https://doi.org/10.3201/eid2207.151990.

3. Duffy MR, Chen T-H, Hancock WT, Powers AM, Kool JL, Lanciotti RS, et al. Zika virus outbreak on Yap Island, Federated States of Micronesia. N Engl J Med. 2009;360:2536-43.

4. Steffens I, Wilson K. Chikungunya and Zika virus Special edition. Eurosurveillance. 2014; October:74.
5. Musso D, Gubler DJ. Zika Virus. Nature. 2016;11:10-20.

6. Gatherer D, Kohl A. Zika virus: a previously slow pandemic spreads rapidly through the Americas. J Gen Virol. 2016;97:269-73.

7. Dyer O. Zika virus spreads across Americas as concerns mount over birth defects. Bmj. 2015;6983 December:h6983. https://doi.org/10.1136/bmj.h6983.

8. Souza WV de, Araújo TVB de, Albuquerque M de FPM, Braga MC, Ximenes RA de A, Miranda-Filho D de B, et al. Microcefalia no Estado de Pernambuco, Brasil: características epidemiológicas e avaliação da acurácia diagnóstica dos pontos de corte adotados para notificação de caso. Cad Saude Publica. 2016;32:1-7. https://doi.org/10.1590/0102-311X00017216.

9. França GVA, Schuler-Faccini L, Oliveira WK, Henriques CMP, Carmo EH, Pedi VD, et al. Congenital Zika virus syndrome in Brazil: a case series of the first 1501 livebirths with complete investigation. Lancet. 2016;388:891-7. https:// doi.org/10.1016/S0140-6736(16)30902-3.

10. MINISTÉRIO DA SAÚDE. Nota informativa $n^{0}$ 01/2015 - coes microcefalias. 2015.

11. Schuler-Faccini L, Ribeiro EM, Feitosa IM, et al. Possible Association Between Zika Virus Infection and Microcephaly — Brazil, 2015. MMWR Morb Mortal Wkly Rep. 2016;65:59-62. https://doi.org/10.15585/mmwr.mm6503e2.

12. Microcephaly Epidemic Research Group. Microcephaly epidemic research group. Microcephaly in infants, Pernambuco state, Brazil, 2015. Emerg Infect Dis. 2016;22:1090-3. https://doi.org/10.3201/eid2206.160062.

13. Rasmussen SA, Jamieson DJ, Honein MA, Petersen LR. Zika Virus and Birth Defects - Reviewing the Evidence for Causality. N Engl J Med. 2016;374: 1981-87. https://doi.org/10.1056/NEJMsr16043381-7.

14. MINISTÉRIO DA SAÚDE. Ministério da Saúde confirma relação entre vírus Zika e microcefalia. 2015. http://www.brasil.gov.br/saude/2015/11/ministerio-dasaude-confirma-relacao-entre-virus-zika-e-microcefalia. Accessed 9 Jan 2018.

15. Velho T, Araújo B De Rodrigues LC, Arraes R, Ximenes DA, Miranda-filho DDB. Association between Zika virus infection and microcephaly in Brazil, January to May , 2016 : preliminary report of a case-control study. 2016;16 December:1356-63.

16. Bermudez-Tamayo C, Mukamana O, Carabali M, Osorio L, Fournet F, Dabiré $K R$, et al. Priorities and needs for research on urban interventions targeting vector-borne diseases: rapid review of scoping and systematic reviews. Infect Dis poverty. 2016;5:104. https://doi.org/10.1186/s40249-016-0198-6.

17. Braga C, Luna CF, Martelli CMT, de Souza WV, Cordeiro MT, Alexander N, et al. Seroprevalence and risk factors for dengue infection in socioeconomically distinct areas of Recife. Brazil Acta Trop. 2010;113:234-40.

18. FPM de Albuquerque M. Urbanização, favelas e endemias: a produção da filariose no Recife, Brasil. Cad Saude Publica 1993;9:487-497. https://doi.org/ 10.1590/S0102-311X1993000400009.

19. Braga C, De Albuquerque MDFM, Schindler H, Rezende A, Maciel A, Silva MCME, et al. Epidemiological pattern of limphatic filariasis in children living in endemic areas. J Pediatr. 1997;73:95-100.

20. Netto MJ, Bonfim C, Brandão E, Aguiar-Santos AM, Medeiros Z. Burden of lymphatic filariasis morbidity in an area of low endemicity in Brazil. Acta Trop. 2016;163:54-60. https://doi.org/10.1016/j.actatropica.2016.07.006.

21. Instituto Brasileiro de Geografia e Estatística. IBGE _ Cidades _ Infográficos _ Pernambuco _ Recife _ Dados Gerais. 2016.

22. Paim J, Travassos C, Almeida C, Bahia L, Maclnko J. The Brazilian health system: history, advances, and challenges. Lancet. 2011;377:1778-97.

23. Banco Central Do Brasil. Conversão de Moedas. Resultado da Conversão. 2014;3426001. http://www4.bcb.gov.br/pec/conversao/conversao.asp. Accessed 9 Jan 2018.

24. Censo. IBGE Censo 2010. Instituto Brasileiro de Geografia e Estatística. 2010. http://censo2010.ibge.gov.br/.

25. Jain AK. Data clustering: 50 years beyond K-means. Pattern Recogn Lett. 2010;31:651-6.

26. Instituto Brasileiro de Geografia e Estatística. SIRGAS Project (Geocentric Reference System for the Americas). 2016. http://www.ibge.gov.br/home/ geociencias/geodesia/sirgas/principal.htm.

27. Regis L, Souza WV, Furtado AF, Fonseca CD, Silveira JC, Ribeiro PJ, et al. An entomological surveillance system based on open spatial information for participative dengue control. An Acad Bras Cienc. 2009;81:655-62.

28. Barreto ML, Teixeira MG, Bastos Fl, Ximenes RA, Barata RB, Rodrigues LC. Successes and failures in the control of infectious diseases in Brazil: social and environmental context, policies, interventions, and research needs. Lancet. 2011;377:1877-89. https://doi.org/10.1016/S0140-6736(11)60202-X.

29. Alirol E, Getaz L, Stoll B, Chappuis F, Loutan L. Urbanisation and infectious diseases in a globalised world. Lancet Infect Dis. 2011;11:131-41. https://doi. org/10.1016/S1473-3099(10)70223-1. 